\title{
XLMR in MRX families 29, 32, 33 and 38 results from the dup24 mutation in the ARX (Aristaless related homeobox) gene Monica L Stepp ${ }^{1}$, A Lauren Cason ${ }^{1}$, Merran Finnis ${ }^{2}$, Marie Mangelsdorf ${ }^{2,3}$, Elke Holinski-Feder ${ }^{4}$, David Macgregor ${ }^{5}$, Andrée MacMillan ${ }^{6}$, Jeanette JA Holden ${ }^{7}$, Jozef Gecz ${ }^{2,3}$, Roger E Stevenson ${ }^{1}$ and Charles E Schwartz*1
}

\begin{abstract}
Address: ${ }^{1}$ J.C. Self Research Institute, Genetic Center, Greenwood, S.C., USA, ${ }^{2}$ Department of Genetic Medicine, Women's and Children's Hospital, Adelaide, Australia, ${ }^{3}$ Department of Pediatrics, The University of Adelaide, Adelaide, Australia Ottawa Health Research Institute, Ottawa, Ontario, Canada, ${ }^{4}$ Medizinisch Genetisches Zentrum, Bayerstrasse 53, D-80335, Munchen, Munich, Germany, ${ }^{5}$ Provincial Medical Genetics Program, St. John, Newfoundland, Canada, ${ }^{6}$ Provincial Medical Genetics Program, Health Science Centre, St. John, Newfoundland, Canada and ${ }^{7}$ Department Psychiatry \& Physiology, Queen's University, Kingston, Ontario, Canada

Email: Monica L Stepp - mdlindsey@ggc.org; A Lauren Cason - cason@musc.edu; Merran Finnis - merranfinnis@yahoo.com; Marie Mangelsdorf - mmangelsdorf@ohri.ca; Elke Holinski-Feder - Holinski-Feder@mgz-muenchen.de; David Macgregor - david.macgregor@hccsj.nl.ca; Andrée MacMillan - Andree.MacMillan@ hccsj.nf.ca; Jeanette JA Holden - holdenj@post.QueensU.CA; Jozef Gecz - jozef.gecz@ adelaide.edu.au; Roger E Stevenson - res@ggc.org; Charles E Schwartz* - ceschwartz@ggc.org

* Corresponding author
\end{abstract}

Published: 25 April 2005

BMC Medical Genetics 2005, 6:16 doi:10.1 186/1471-2350-6-16
Received: 29 November 2004

Accepted: 25 April 2005

This article is available from: http://www.biomedcentral.com/I47/-2350/6/16

(C) 2005 Stepp et al; licensee BioMed Central Ltd.

This is an Open Access article distributed under the terms of the Creative Commons Attribution License (http://creativecommons.org/licenses/by/2.0), which permits unrestricted use, distribution, and reproduction in any medium, provided the original work is properly cited.

\begin{abstract}
Background: $X$-linked mental retardation (XLMR) is the leading cause of mental retardation in males. Mutations in the ARX gene in Xp22.I have been found in numerous families with both nonsyndromic and syndromic XLMR. The most frequent mutation in this gene is a 24 bp duplication in exon 2. Based on this fact, a panel of XLMR families linked to Xp22 was tested for this particular ARX mutation.

Methods: Genomic DNA from XLMR families linked to Xp22.I was amplified for exon 2 in ARX using a Cy5 labeled primer pair. The resulting amplicons were sized using the ALFexpress automated sequencer.

Results: A panel of I I families with X-linked mental retardation was screened for the ARX 24dup mutation. Four nonsyndromic XLMR families - MRX29, MRX32, MRX33 and MRX38 - were found to have this particular gene mutation.

Conclusion: We have identified 4 additional XLMR families with the ARX dup24 mutation from a panel of I I XLMR families linked to Xp22.I. This finding makes the ARX dup24 mutation the most common mutation in nonsyndromic XLMR families linked to Xp22.I. As this mutation can be readily tested for using an automated sequencer, screening should be considered for any male with nonsyndromic MR of unknown etiology.
\end{abstract}




\section{Background}

The causes of mental retardation (MR) are exceptionally heterogeneous. More than 50 genes found on the human $\mathrm{X}$ chromosome have been reported to cause MR with another 150 loci being associated with linked syndromes, nonsyndromic families and unlinked syndromes [1,2]. The aristaless-related homeobox gene, ARX, maps to Xp22.1-p21.3, encompasses a genomic region of approximately $12.5 \mathrm{~kb}$ and is composed of 5 encoding exons [3]. The most frequent mutation reported in ARX is an inframe 24 bp duplication in exon 2, which causes an expansion of the polyalanine tract at amino acid positions 144-155, from 12 to 20 alanines. This duplication has been reported in a Norwegian family with West Syndrome $[3,4]$ as well as four published nonsyndromic XLMR families, MRX36 [5], MRX43, MRX54 and MRX76 [6]. We have recently identified the same 24 bp duplication in 4 other nonsyndromic XLMR families linked to Xp22.1: MRX29 [7], MRX32 [8], MRX33 [9], and MRX38 [10].

\section{Methods}

Genomic DNA from members of eleven XLMR families linked to Xp22.1, a West Syndrome family with a 21 bp insertion [3], two positive controls for the 24 bp duplication (dup24) [3], and a negative control was amplified by PCR using locus specific primer pairs designed for exon 2 of ARX. The Cy5 labeled forward primer sequence, ARXex2P1, was 5'ACG CCT GGG CCT AGG CAC TG 3' and the reverse primer sequence, ARXex2P1, was 5' CTC GGT GCC GGT GCC ACC AC 3'. These primers flank both the (GCG) $)_{10+7}$ and dup24 mutations. The size of the normal control PCR product is $584 \mathrm{bp}$, while the (GCG) $)_{10+7}$ mutation gives a 605 bp product and the dup 24 mutation a 608 bp product. The parameters of the reaction consisted of an initial denaturation at $95^{\circ} \mathrm{C}$ followed by 30 cycles consisting of $95^{\circ} \mathrm{C}$ for 30 seconds, $62^{\circ} \mathrm{C}$ for $30 \mathrm{sec}-$ onds, and $72^{\circ} \mathrm{C}$ for 30 seconds and completing with a final extension at $72^{\circ} \mathrm{C}$ for 5 minutes. PCR amplification was verified using a $1.5 \%$ agarose gel, run at 120 volts, and stained with ethidium bromide. PCR products were then analyzed using the Amersham Biosciences ALFexpress 1.

\section{Results}

The analysis revealed an altered pattern in a female carrier of MRX38 and one affected male from each of three other families: MRX29, MRX32, MRX33 (Figure 1). The pattern was identical to that observed for two samples known to have the dup 24 mutation in exon 2 of ARX and clearly distinct from the $21 \mathrm{bp}$ insertion in exon 2 that is present in the patient with West Syndrome (Figure 1). DNA sequencing of the PCR products confirmed the presence of the dup24 mutation. It is important to note the discrepancy in the size of the dup24 mutation and the sizing standard in lanes 1 and 4 (Figure 1). We hypothesize that the slower migration pattern observed for the dup24 mutation ( 645 bp instead of the expected $608 \mathrm{bp}$ ) is due to its secondary (hairpin) structure.

\section{Discussion}

We have identified the dup24 mutation in exon 2 of ARX in four additional nonsyndromic XLMR families (MRX29, 32, 33, and 38) linked to Xp22.1. This same alteration has been observed in four other published nonsyndromic families, MRX36 [5], MRX43, MRX56 and MRX76 [6] linked to $\mathrm{Xp} 22.1$. As a result, this single mutation accounts for $8 / 11(73 \%)$ of MRX families linked to $\mathrm{Xp} 22.1$ [11]. This $24 \mathrm{bp}$ duplication is not restricted to nonsyndromic XLMR families. A family with West syndrome linked to Xp22.1 had this alteration [4], as well as 2 families with Partington syndrome, also linked to Xp22.1 [3]. This association of nonsyndromic and syndromic XLMR with the 24 bp duplication has also been noted by Kato et al [12].

The dup24 also accounts for 2/10 (20\%) syndromic XLMR conditions linked to Xp22.1 $[13,14]$. This is quite striking and noteworthy since for most XLMR genes described thus far, mutations are found in less than $20 \%$ of families linked to any particular region [15]. Overall, it appears that when all mutations in ARX are considered, alterations in the gene accounts for 4/58 (7\%) syndromic and $8 / 24(25 \%)$ nonsyndromic XLMR conditions with known gene defects. Again, this is uncharacteristic of other XLMR genes, except for ATRX/XNP (mutations in 6 syndromes) or PQBP1 (mutations 5 syndromes) [14].

This being said, there is a "disconnect" when screening for ARX mutations is expanded to the general male MR population. Bienvenu et al. [6] were only able to identify two mutations in a panel of 148 XLMR families and only one dup24 mutation in 40 sporadic males with MR. Additionally, Gronskov et al. [16] identified only one dup24 mutation out of 682 patients. Other studies experienced a similar failure to find this mutation in 577 males with non-fragile X MR (Stepp and Schwartz, unpublished) and a cohort of 188 male patients [15]. This translates to a positive screen rate of 2/1501 male patients with MR, significantly different from the $6.6 \%$ rate observed in proven XLMR families [15].

At present, there is no clear explanation for this disparity in the frequency of ARX mutations between families with XLMR linked to Xp22.1 and sporadic cases of males with MR. It may simply mean that the assumption that the 25$30 \%$ excess of males with MR is due to genes on the $\mathrm{X}$ chromosomes is incorrect. Therefore, the male excess in the MR population might have to be accounted for by other mechanisms including yet to be revealed X-chromosome linked factors. 


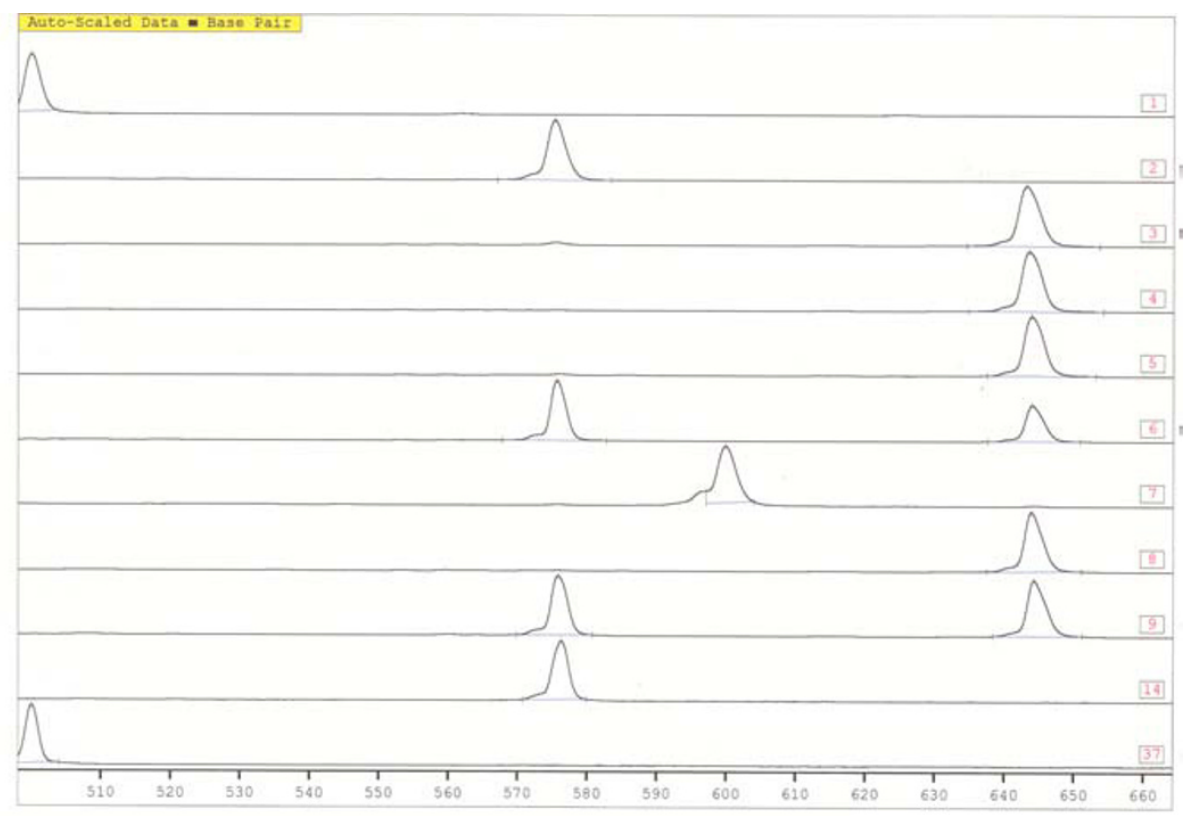

Ladder

Normal control

MRX29

MRX32

MRX33

MRX38

Affected $(\mathrm{GCG})_{10+7}$ male

Affected dup24 male

Carrier female with dup24

Normal control

Ladder

\section{Figure I}

Chromatograph of samples with ARX 24dup mutation. Lane 17 is the $50-500$ bp ladder lanes. Lane I4 is a normal control. Lane 3 is an affected male from MRX29. Lane 4 is an affected male from MRX32. Lane 5 is an affected male from MRX33. Lane 6 is a female carrier from MRX38. Lane 7 is a male with (GCG) I0+7 ARX mutation. Lane 8 is an affected male with a known dup24 mutation and Lane 9 is a female carrier with the dup24 mutation.

\section{Conclusion}

In conclusion, we have shown that 4 additional MRX families (MRX29, 32, 33 and 38), mapped to Xp22.1, have the dup24 mutation in exon 2 of the ARX gene. This mutation accounts for about 70\% of MRX families linked to Xp22.1. However, it has been difficult to find this same mutation in large cohorts of males with mental retardation. Nonetheless, as the 24dup mutation in ARX can easily be tested using an automated DNA sequencer, screening of males with MR of unknown etiology for this particular mutation should be given consideration.

\section{Competing interests}

The author(s) declare that they have no competing interests.

\section{Authors' contributions}

MLS, ALC, MF and MM carried out the molecular genetics studies. EH-F, DM, AM, JJAH and RES provided clinical material. JG and CES drafted the manuscript. CES conceived the study and participated in its design and coordination. All authors read and approved the final manuscript.

\section{Acknowledgements}

This work has been supported by grant HD26202 from NICHD (CES), the National Health and Medical Research Council of Australia (JG) and in part, by the South Carolina Department of Disabilities and Special Needs (RES). This paper is dedicated to the memory of Ethan Francis Schwartz (19961998).

\section{References}

I. Chelly J, Mandel JL: Monogenic causes of $\mathbf{X}$-linked mental retardation. Nat Rev Genet 200I, 2:669-680.

2. Stevenson RE, Schwartz CE: Clinical and molecular contributions to the understanding of $\mathrm{X}$-linked mental retardation. Cytogenet Genome Res 2002, 99:265-275.

3. Stromme P, Mangelsdorf ME, Shaw MA, Lower KM, Lewis SM, Bruyere $\mathrm{H}$, Lutcherath V, Gedeon AK, Wallace RH, Scheffer IE, Turner G, Partington M, Frints SG, Fryns JP, Sutherland GR, Mulley JC, Gecz J: Mutations in the human ortholog of Aristaless cause $X$ linked mental retardation and epilepsy. Nat Genet 2002, 30:44I-445.

4. Stromme P, Sundet K, Mork C, Cassiman JJ, Fryns JP, Claes S: X linked mental retardation and infantile spasms in a family: new clinical data and linkage to Xp I I.4-Xp22.I I. J Med Genet 1999, 36:374-378.

5. Frints SG, Froyen G, Marynen P, Willekens D, Legius E, Fryns JP: Reevaluation of MRX36 family after discovery of an ARX gene mutation reveals mild neurological features of Partington syndrome. Am J Med Genet 2002, I 1 2:427-428.

6. Bienvenu T, Poirier K, Friocourt G, Bahi N, Beaumont D, Fauchereau F, Ben Jeema L, Zemni R, Vinet MC, Francis F, Couvert P, Gomot M, Moraine C, van Bokhoven H, Kalscheuer V, Frints S, Gecz J, Ohzaki 
K, Chaabouni H, Fryns JP, Desportes V, Beldjord C, Chelly J: ARX, a novel Prd-class-homeobox gene highly expressed in the telencephalon, is mutated in $\mathbf{X}$-linked mental retardation. Hum Mol Genet 2002, I I:98I-99I.

7. Hane B, Schroer RJ, Arena JF, Lubs HA, Schwartz CE, Stevenson RE: Nonsyndromic $X$-linked mental retardation: review and mapping of MRX29 to Xp2I. Clin Genet 1996, 50: I76-I83.

8. Hane B, Stevenson RE, Arena JF, Lubs HA, Simensen RJ, Schwartz CE: Gene for apparently nonsyndromic $X$-linked mental retardation (MRX32) maps to an I8-Mb region of Xp2I.2-p22. Am J Med Genet 1999, 85:27I-275.

9. Holinski-Feder E, Golla A, Rost I, Seidel H, Rittinger O, Meindl A: Regional localization of two MRX genes to Xq28 (MRX28) and to XpII.4-Xp22.12 (MRX33). Am J Med Genet 1996, 64: $125-130$.

10. Schutz CK, Ives EJ, Chalifoux M, MacLaren L, Farrell S, Robinson PD, White BN, Holden J]: Regional localization of an X-linked mental retardation gene to Xp2I.I-Xp22.I3 (MRX38). Am J Med Genet 1996, 64:89-96.

II. Linkage limits for 48 XLMR syndromes which have been mapped (lod score >2), but the genes not yet cloned 2004 [http://www.ggc.org/xImr.htm].

12. Kato M, Das S, Petras K, Kitamura K, Morohashi K, Abuelo DN, Barr M, Bonneau D, Brady AF, Carpenter NJ, Cipero KL, Frisone F, Fukuda T, Guerrini R, lida E, Itoh M, Lewanda AF, Nanba Y, Oka A, Proud VK, Saugier-Veber P, Schelley SL, Selicorni A, Shaner R, Silengo M, Stewart F, Sugiyama N, Toyama J, Toutain A, Vargas AL, Yanazawa M, Zackai EH, Dobyns WB: Mutations of ARX are associated with striking pleiotropy and consistent genotype-phenotype correlation. Hum Mutat 2004, 23: I47-I59.

13. Linkage limits for $\mathbf{5 5}$ MRX families which have been mapped (lod score >2). The locations of the 9 MRX genes which have been cloned are indicated by the solid arrows, 6 genes that cause MRX and MRXS are shown with open arrows 2004 [http://www.ggc.org/xlmr.htm].

14. Location of the $\mathbf{3 4}$ genes for XLMR syndromes which have been cloned and mutations demonstrated 2004 [http:// www.ggc.org/xlmr.htm].

15. Mandel JL, Chelly J: Monogenic $\mathbf{X}$-linked mental retardation: is it as frequent as currently estimated? The paradox of the ARX (Aristaless X) mutations. Eur J Hum Genet 2004, I 2:689-693.

16. Gronskov K, Hjalgrim H, Nielsen IM, Brondum-Nielsen K: Screening of the ARX gene in $\mathbf{6 8 2}$ retarded males. Eur J Hum Genet 2004, I 2:701-705.

\section{Pre-publication history}

The pre-publication history for this paper can be accessed here:

http://www.biomedcentral.com/1471-2350/6/16/prepub
Publish with Biomed Central and every scientist can read your work free of charge

"BioMed Central will be the most significant development for disseminating the results of biomedical research in our lifetime. "

Sir Paul Nurse, Cancer Research UK

Your research papers will be:

- available free of charge to the entire biomedical community

- peer reviewed and published immediately upon acceptance

- cited in PubMed and archived on PubMed Central

- yours - you keep the copyright
BioMedcentral 